\title{
Kentlileşmeden Kentleşme ve Kadına Şiddetin Sosyal Dinamikleri
}

\author{
DOI: 10.26466/opus. 913097
}

\author{
* \\ Esmeray Alacadağ $l_{1}^{*}$ \\ * Dr. Öğr. Üyesi, Bayburt Üniversitesi, İ̈BF, Bayburt/Türkiye \\ E-Posta: ealacadagli@bayburt.edu.tr \\ ORCID: $\underline{0000-0003-1604-6487}$
}

\section{Öz}

Kentleşme, demografik açıdan, kentlerde yaşayan nüfusun artmasını anlatan bir kavramdır. Ülkemizde, 1950'li yıllar sonrasında kentlerde yaşayan birey sayısı sürekli artarak, günümüzde \%93 düzeyine ulaşmıştır. Kentleşmenin ekonomik, toplumsal boyutları da vardır. Çünkü, gerekli altyapı ve istem oluşmadan hızla artan kentleşme genellikle; işsiz, gizli işsizi bol kentlerin oluşumuna, kentleşen ama kentlileşemeyen yani kentle bütünleşemeyen bir toplumsal yapının ortaya çıkmasına yol açmaktadır. Genelde, kent varoşlarında yerleşerek yaşamların sürdürmeye çalışan bu yapı, büyük oranda, geçimini kente özgü işlerle sağlayamayan, her konuda kente özgü tavır ve davranış biçimleri ve değerleri benimseyemeyen kitlelerden oluşmaktadır. Bu kitleler, o kentte ve kent kültürüne eklemlenme yerine göç ettiği yerlerin hakim değerleriyle ayakta kalmaya çalışırken kente kent değerlerine yabanculaşmakta, artan marjinalleşmeye bağh olarak toplum dışı davranış ve şiddete eğilimler de artmaktadır. Literatür taramasına dayalı olarak yapılan bu çalışmayla, son günlerde toplumumuzda giderek artan kadına yönelik şiddetin nedenleri, göç, kentlileşme ve yoksulluk olgular bağlamında incelenerek çözüm önerileri oluşturmak amaçlanmıştır. Araştırma sonuçları kadına yönelik şiddette, kentlileşememe ve yoksulluğun önemli bir etken olduğunu ortaya koymaktadır.

Anahtar Kelimeler: Kentlileşme, Yoksulluk, Kadına Şiddet, Varoş Kültürü̈. 


\title{
Non-Urbanization and Social Dynamics of Violence against Women
}

\begin{abstract}
Urbanization is a concept that defines the increase in the population living in cities in terms of demographics. In Turkey, the number of individuals living in urban areas increased continuously after the 1950s and reached around $93 \%$ as of today. However, urbanization also has economic and social dimensions. Because, rapidly increasing urbanization without sufficient infrastructure and demand generally leads to formation of cities with underlying unemployment, and the emergence of a social structure that is urbanized but not localized, ultimately not being able to integrate with the city. Generally, this social segment tries to survive by settling in the urban suburbs, consists largely of the masses who are not able earn their living with urban-jobs, and who ultimately cannot adopt urbanspecific behaviors, lifestyles and values. Hence, these masses try to survive in the city and with the dominant values of the places they came from, instead of integrating to the city culture, which leads to their alienation to city values, resulting alienation and potential tendencies towards violence due to increasing marginalization.This literature review-based study aims to provide solutions by analyzing the causes of the violence against women, which has recently been increased in our society, in the context of migration, urbanization and poverty phenomenon. Research results reveal the importance of nonurbanization and poverty, as being factors for violence against women.
\end{abstract}

Keywords: Urbanization, Violence Against Women, Poverty, Suburban Culture. 


\section{Giriş}

Şiddet; insan unsurunun bulunduğu her yerde, farklı biçim ve türde karşımıza çıkan, süreç içinde doğal olarak farklılaşan, değişen ve dönüşen ve bu bağlamda birçok tanımı bulunan bir kavramdır. 2012 yılında yürürlüğe giren "Ailenin Korunması ve Kadına Karşı Şiddetin Önlenmesine Dair Kanun"da şiddet: "Kamusal veya özel alanda meydana gelen ve kişinin, fiziksel, cinsel, psikolojik veya ekonomik açıdan zarara uğramasına, acı çekmesine yol açan veya açma ihtimali olan hareketler ile bunu amaçlayan tehditler, baskılar veya özgürlüğünü keyfî olarak engelleyen, toplumsal, fiziksel, cinsel, psikolojik, sözlü veya ekonomik her türlü tutum ve davranış" olarak tanımlanmaktadır. Dünya Sağlık Örgütü'ne göre şiddet, "fiziksel güc, veya iktidarın, kasıtlı olarak tehdit veya bir gerçeklik biçiminde birine uygulanması sonucunda, maruz kalan kişide yaralanma, ölüm ve psikolojik zarara yol açması ya da açma olasılığ bulunması" durumudur (Uğurluoğlu, 2018).

Şiddet kişileri fiziksel, duygusal ve sosyal olarak etkileyen bir olgudur. Günümüzde toplumsal cinsiyet rollerine, güçsüz ve savunmasız olmalarına bağlı olarak şiddetten en çok etkilenenler; kadınlar, çocuklar, yaşlılar ve engellilerdir. Kadına şiddet, sadece kadının ve ailesinin yaşamını, yaşam standartlarını tehdit eden bir olay değildir. Toplumun yaklaşık yarısını oluşturan kadına uygulanan ve onu her açıdan olumsuz etkileyen şiddet, toplumsal yaşam üzerinde de pek çok olumsuz etkisi olan, toplum sağlığ 1 ve huzurunu tehdit eden önemli bir sosyal sorundur. Bu nedenle bu soruna çözüm arama, tüm toplumların üzerinde öncelikle durduğu bir konudur.

$\mathrm{Bu}$ çalışmanın amacı insanlık tarihiyle birlikte seyreden ancak günümüzde giderek artarak gündelik yaşamımızı tehdit eden boyutlara ve kimliğimizi tanımlayan bir unsura dönüşen şiddetin, özellikle son günlerde toplumumuzda artan kadına yönelik şiddetin nedenlerini, yoksulluk, göç ve kentlileşememe olguları bağlamında inceleyerek çözüm önerileri oluşturmaktır. 


\section{Çalışmanın Önemi ve Yöntemi}

Türkiye'de kadına yönelik şiddet ve giderek artan kadın cinayetleri, nedenleri ortaya konarak ivedilikle önlem alınması gereken bir problemdir. Bu kapsamda, bu soruna çözüm aramak üzere, hem sivil toplum hem de kamu kuruluşlarınca çalışmalar yapılmaktadır. Ancak Türk toplumunda kadınların büyük çoğunluğu, ataerkil aile yapısı içinde, erkeğin güç öğesi ve kadından daha üstün konumda olduğunun kabullenildiği bir "erkek çocuk" algısı, erkeğe itaat anlayışı ile yetiştirilmektedir. Temel sorumluluğunun annelik olduğu öğretisiyle, erkeğin istemlerine öncelik vermeyi ve ona koşulsuz itaate şartlanan kadınların çoğu, aile içinde şiddete uğrasa da toplumda baskın olan kültür ve bu konunun aile mahremiyeti içinde kalması düşüncesiyle hareket etmektedir. Küçük yaşlardan itibaren cinsiyet ayrımcılığına dayalı sınırlamalarla yetiştirilen kadının kent yaşamına birey olarak eklemlenmesi de bu nedenle çok kolay olmamakta, erkeğe bağlı olarak şekillenmektedir.

Erkek egemen kültürün ve "kocasıdır, babasıdır, ağabeyidir sever de döver de" ön kabulünün baskın olduğu Türk toplumunda, aile mahremiyeti olarak üstü örtüldügünden, kadına ve kadına şiddete yönelik, akademik ve sayısal çalışmaların sayısı oldukça kısıtlıdır (Ediz ve Altan, 2017, s.398). Özellikle bu durumu kentleşme, kentlileşme ve onu etkileyen yoksulluk gibi unsurlar bağlamında inceleyen çok fazla çalışma bulunmamaktadır. Bu nedenle, kadına yönelik şiddette, kentlileşememenin, kent kültürüne uyum sağlayamamanın, etkilerini ortaya koyması ve çözüm önerileri sunmaya çalışması açısından bu çalışmanın önemli olduğu düşünülmektedir.

Literatür taraması yöntemiyle yapılan bu çalışmada, öncelikle sorunsalla ilgili tüm konularda -hem kentlileşme hem de kadına yönelik şiddete yönelik çalışmalar, raporlar, medya kaynakları vd- literatür taramasına dayalı olarak veriler toplanarak çalışmanın teorik ve kavramsal çerçevesi oluşturulmuştur. Daha sonra bu konudaki faaliyet/araştırma raporları, araştırmalar, dönemsel istatistikler, izlemeler gibi bilgilerden yararlanılarak mevcut durum ortaya konulmuş ve belirleyici olan temel dinamiklerle etkileşimi ortaya koyacak biçimde veri analizi yapılarak sonuca ulaşılmış ve çözüm önerileri oluşturulmuştur. 


\section{Göç, Yoksulluk, Kentlileşememe, Varoş Kültürü ve Kadına Şiddet}

Göç, kişilerin çeşitli nedenlere dayalı olarak gönüllü ya da zorunlu olarak ya ülke içinde bir coğrafi alandan diğerine -genelde de kırdan kente- ya da bir ülkeden diğerine yer değiştirmeleri hareketidir. Bu hareketin sonuçlarından biri kentleşme olup kentleşme; insanların kırsal alanlardan kente göç etmesi sonucu kent sayısı ve kent nüfusunun artması olarak ifade edilebilir. Ancak bu tanım, kentleşmenin sadece demografik yönünü ifade etmekte olup eksik bir tanımlamadır. Çünkü kentleşme, ekonomik olarak işgücünün tarımdan sanayi ve hizmet sektörüne kaymasını, kültürel açıdan ise kırdan kente göç eden nüfusun, kent kuralları ve yaşam tarzını benimsemesini içermekte bu bağlamda ekonomik ve sosyokültürel değişimlere de yol açmaktadır. Kentlileşme diye tanımlanan ve ekonomik olarak kişinin geçimini kentte ve kente özgü iş ve sektörlerde -sanayi, hizmet gibi- istihdamla sağlayacak duruma gelmesi demek olan bu değişim, sosyal ve kültürel anlamda kişilerce kente özgü davranış biçimlerinin, sosyal ve kültürel değer yargılarının benimsenmesiyle gerçekleşmektedir (Es ve Ateş, 2004, s.215; Keleş, 2016, s.22-31).

Kirdan kente göç eden kitlelerin ekonomik ve sosyal dönüşümünün kendi mecrasında akarak beklenen süreçte gerçekleştiği durumlarda, göçün bireyler, toplum ya da kent açısından yol açtığı sorunlar çok önemli değildir. Ancak ekonomik ve sosyal açlardan bu değişim/dönüşümün bir başka ifadeyle kentlileşmenin sağlanamadığı durumlarda bu durumun öncelikle bireyler sonrasında toplum ve kent açısından önemli sonuçları vardır. Bu sürecin sağlıksız yürüdüğü durumlarda bireyler; bir yandan ekonomik açıdan beklentilerini karşılayamamaları sonucu kırda yaşadıkları yoksulluğu yerinden yurdundan uzakta ve daha derin bir biçimde kentte yaşamakta, diğer yandan sosyo-kültürel açıdan kendi kültürüyle kent kültürü arasında sıkışmanın yol açtığı davranış bozuklukları ve uyumsuzluklar göstermektedir. Çünkü kentlileşme, bünyesinde çağdaş yaşamı, uygarlığı, bu yaşamın gerektirdiği kimlikleri ve derinliğine bir toplumsal hayatı barındıran bir yaşam biçimidir (Parlak, 2011, s.453). Bu bilince, ruha sahip olamadan kente sadece fiziken, bedenen dahil olan ve sosyo-kültürel ve sosyo-psikolojik açıdan uyum sağlayamayan bireyler ise kente yabancllaşmakta ve kendilerini ifade edebilecekleri, aidiyet duygularını karşılayabilecekleri farklı gruplara 
yönelmektedirler. Kentsel başkalaşma ya da kentsel yabancılaşma olarak da tanımlanan bu yöneliş; cemaatleşme, gettolaşma, mekânsal ve kültürel siteleşme (Parlak, 2008, s.67) gibi sosyo mekânsal bölünmelerle tepkiselliği, şiddeti ve suça itilmeyi artırmakta, önemli toplumsal sorunlara yol açmaktadır.

Ülkemizde 1950'lerde başlayan göçlerle o dönemlerde nüfusu 10.000'i aşan kentlerde \%18.5 (il, ilçe merkezlerinde bu oran \%25) olan kent nüfusu 2000'lerde \%65'e (Keleş, 2016, s.66-67), günümüzde \%93'e ulaşmıştır (TÜIK, 2021 Adrese Dayalı Nüfus Verileri). Ancak bu orana bakarak, Türkiye'nin kentleştiğini, kentlileştiğini söylemek pek mümkün değildir. Öncelikle bu oranda siyaseten alınan kararlarla yerel yönetimlere yönelik mevzuat değişikliğinin -yani belediye ve büyükşehir belediyesi kanunlarındaki değişikliğin- büyük etkisi vardır. Öte yandan Türkiye kentleşmesi, kırdan kente tek yönlü göç şeklinde gerçekleşmiş, refahı, gelişmeyi yeterli ölçüde sağlayarak, sağlıklı kentleşmeyi ve kentlileşmeyi sağlayacak bir süreç olarak gelişmemiştir. Bir başka ifadeyle Türkiye'de kentleşme, sanayinin gelişmesi ve işgücünün istihdamını sağlayarak kalkınmanın itici gücü olacak şekilde gelişememiştir. Bu nedenle kırsal kesimden kente göç eden insanlar, genellikle işsiz, gizli işsizi bol kentler meydana getirmişlerdir. Çünkü kente göç eden işsiz kesim genelde nitelikli işgücünü gerektirmeyen işlerde istihdam edilmiş, "marjinal sektör" dediğimiz bir istihdam türü oluşturarak kent işsizliğinin de fazlalaşmasına neden olmuştur. Bu durum göçle gelen insanların kente yabancılaşarak kentlileşememelerinin ve birçok sosyal problemin kaynağını oluşturmuştur (Keleş, 2016, s.74-81). Bu bağlamda ülkemiz kentleşmesi, ekonomik açıdan; işsizlik, sektörler ve bölgelerarası gelişmede dengesizlik, altyapı hizmetlerinde tıkanma, barınma sorunlarına ve kamu arazilerinin gecekondu denilen barınma yuvalarıla işgaline, sosyal açıdansa; gelir dağılımındaki eşitsizliğe, sosyal tabakalaşmanın, sınıflaşmanın ve gettolaşmanın artmasına, kültürel değişimde yaşanan sorunlar ve boşluklara dayalı olarak toplum hayatında çözülme ve uyumsuzluklara, suça, şiddete yönelmeye yol açmıştır (Sezal, 1992, s.74-78; Parlak, 2008, s.67).

Ekonomik güçlük, daha iyi yaşama isteği, kan davasından kaçmak gibi çeşitli nedenlerle yaşadıkları yerleri değiştirmek durumunda kalan insanların, geldikleri kentte karşı karşıya kaldıkları barınma sorununu, 
genel-likle insanca bir yaşam sürdürmek için çok uygun olmayan ve batıda yoksulluk yuvaları, bizde gecekondu denilen mekanlarla çözmeye çalışmaları, ülkemizde özellikle İstanbul, Ankara, İzmir gibi büyük kentlerin çevresinde varoş olarak tanımlanan, kentle uyumsuzluk sorunu yaşayan yerleşimleri ortaya çıkarmıştır (Tatar, 2009, s.3). Bu hiçbir fiziki plana dayanmayan plansız, yasadışı yerleşimler ve yerleşme düzensizliği, çevresel değerlerinin bozulmasına neden olmanın yanında kamu kaynaklarının yitirilmesine de yol açmıştır.

Keleş'e göre; ülkemizde gecekondu diye adlandırılan olgu yalnızca bir barınma sorunu değildir. Aslında bu mekânsal yerleşimler, gelişmiş ve de gelişmekte olan ülkelerdeki kente göçün, nüfus akınının bir sonucu ve bu ülkelerin toplumsal, ekonomik gelişme düzeyinin ortaya çıkardığı bir üründür. Batıda ya da ülkemizde bu tür yerlerde yaşayanlar, toplumun dar gelirli ve yoksul kesimleri olup, aynı zamanda niteliksiz işgücünü de oluşturdukları için hemen istihdam da edilememektedir (Keleş, 1996, s.375). Çünkü kentteki iş yaşamı, uzmanlaşmış ve beceri kazanmış insanları, işgücünü gerektirmektedir. Kent açısından ihtiyaç olan ve yüksek gelir getiren işler, doğal olarak uzmanlığı, yüksek ya da mesleki teknik eğitimi, beceri ve deneyimi zorunlu kılmaktadır. Oysa göçle gelen ve gecekonduda yaşayan nüfusun eğitim düzeyi düşük olup mevcut eğitim düzeyi ve nitelikleriyle bu işlere girememektedir. Bu durum Keleş'in de belirttiği üzere büyük kentlerimize vasıfsız işgücü yığılmasına ve gayrı resmi ve süreklilik arz etmeyen bir sektörün doğmasına yol açmaktadır. Plansız ve kentin talebi dışında oluşan göçlerle büyüyen az gelişmiş toplum kentlerinde, çağdaş sektörlerde istihdam imkanının olmamasının bir sonucu da yoksulluk ve yoksulluk kültürüdür.

2009'da yapılan Kentleşme Şurası Raporu'nda da benzer bir sonuç vurgulanmaktadır. Rapora göre; "kentsel yoksulluğun temel nedenlerinden biri de sanayileşme, kentleşmeye dayalı olarak gerçekleşen göçlerin kentlerde yol açtı̆̆ı nüfus yoğunlaşmasının kentin iş edindirme ve yaşam koşullarını iyileştirme olanaklarını daraltmasıdır." Oluşan kentsel yoksulluk sadece göçle gelenler için değil çalışan kesimler için de geçerlidir. Çünkü bu kesimin artan kente göçlerle hem ücret düzeyleri düşmekte, hem de ticarileşerek paralı hale gelen toplumsal hizmetler, onları giderek daha çok yoksulluk sınırının altına doğru itmektedir. Öte yandan, işsizler, çalışamayan engelliler, yaşlılar, çocuklar ile kadınlar ve 
gençler gibi ev içinde üreten ancak emeğinin ücretini alamayan kesimler yoksulluk düzeyinin en altında yer almaktadırlar (Bayındırlık Bakanlığı, 2009, s.35)

Yoksulluk kavramı mutlak ve göreli yoksulluk olarak tanımlanmaktadır. Mutlak yoksulluk; "hane halkı ya da bireylerin, biyolojik olarak yaşamlarını sürdürebilmek ve kendilerini üretebilmek için gereken asgari gelir ve harcama düzeyine sahip olmaması" olup, gelirle ilgilidir. Göreli yoksulluk ise, kişinin ya da hane halkının, belirli kriterlere göre belirlenen ve içinde yaşadığı toplum tarafından kabul edilen asgari bir yaşam düzeyine sahip olup olmadığıyla ilgilidir. Göreli yoksulluk sahip olunan yaşam düzeyine göre belirlenen bir olgu olup orada farklı grupların sahip olduğu mutlak gelir düzeyi değil, gelir ve refahın dağılımındaki farklılıklardır (World Bank, 2000; Alacadağlı, 2020, s.170). Göreli yoksulluk bu farklılıklara odaklanır. ABD'li antropolog Oscar Lewis tarafından ortaya atılan yoksulluk kültürü kavramı ise; "yoksulluk koşullarına uyum sağlamaya yönelik bir strateji olarak aile içindeki toplumsallaşma mekanizmalarıly gelecek kuşaklara aktarllan, kendine özgü bir yapısı, ussallığı ve savunma araçları olan bir yaşam tarzıdır. Yoksulluk kültürü, toplumun başlıca kurumlarına katılımda yetersizlik, eğitim düzeyinde düşüklük, örgütlü olmama ve geniş toplumun yetkili kurumları karşısında kuşkucu ve sakınmacı davranış biçimiyle belirlenmektedir" (Aktaran Özbudun, 2002, s.60-61). Yoksulluk kültürü yaklaşımına göre yoksulluk; çağdaşlaşma kuramları çerçevesinde, kentle bütünleşememenin bir sonucu olarak ortaya çıkan, alt kültürde gelişen ve suçla birlikte ele alınması gereken bir toplumsal sorundur (Gül ve S. Gül, 2008, s.66-67).

Ülkemizde köyden kente göç ederek gecekondularda barınan, işsizlik ve geçim sıkıntısının yarattığı yoksulluğa kentte yaşamak uğruna katlanan ve yoksulluğu hayatlarının bir parçası olarak algılayan kitleler, bir yandan kendi kimliği, örf, adet ve değerleri ile var olmaya çalışırken öte yandan kente uyum sağlama çabalarıyla arabesk denilen müziği, giyim ve yaşam tarzlarıyla kendilerine özgü bir kültür; "varoş kültürü"nü oluşturmuşlardır. Genel olarak muhafazakar, daha kapalı bir toplumsal yaşam biçimine ve kültürüne sahip olan yoksulluk yuvalarının bireyleri, gerçekte de, kentte doğup büyümüş kent bireyleri ve ailelerinden birçok yönden farklıdırlar. Bu bireylerin ve çekirdek ailelerinin, kırdan kentte göçlerine yol açan sorunlarını; kente uyumda yaşadıkları zorluklar, 
niteliksiz işgücünü olmalarından kaynaklı yaşadıkları işsizlik ve sahip oldukları yetersiz gelir daha da derinleştirmiştir. Bir yandan şehrin insan yaşamını kolaylaştıran konforuna sahip olmaya çalışan diğer yandan kırsaldaki gelenek ve göreneklere uymayan bu yapıyı yadırgayan bu kitleler, değişme-kimliğini koruma sarmalında büyük bocalamalar yaşamışlardır. Bu sarmalda köyden kente göç etmiş gecekondu çekirdek ailesindeki erkek, otoritesini kaybetmemek için etrafındakilerini baskılamış, gerektiğinde şiddete başvurmuş, kadın ve çocuklar ise daha bağımsız olmak isteğiyle bu baskıya direnmişlerdir (Tatar, 2009, s.5; Keleş, 1996, s.388-392). Sonuç olarak daha iyi koşullarda yaşamak üzere kırsal kesimden kentlere göç eden kişilerin, kentlerde bekledikleri yaşantıyı bulamamaları ve kente uyuma bağlı yaşadıkları sorunlara, işsizlik ve ekonomik güçlükler de eklenince, bu kişilerin sorunları da büyümüştür. Ailelerin yaşadıkları kültürel çatışma ve içinde bulundukları yoksulluk, sosyal gerilimlere (Keleş, 1996) ve iç dünyalarında yeni çatışmalara yol açmış, aile bireylerinin duydukları eziklikler aile içi şiddeti de artırmıştır.

Yoksulluk kültürü içinde yetişen çocukların, çok defa dağılmış aile ve şiddetten paylarına düşeni aldığını, eğitim şanslarını kullanamadığını, şiddet eğilimli bu yapının dışardan bir müdahale olmadığında -devlet desteği, korunmaya yönelik politikalar gibi- kuşaktan kuşağa aktarılarak sağlamlaştığını (Kıray, 1982, s.57-66) bu konuda yapılan araştırmalar da ortaya koymaktadır. Bu durumda, güçsüzlügü nedeniyle şiddete uğrayan çocuklar ve kadınlarca gelecek nesillere aktarılan öğrenilmiş çaresizlikler ve davranış biçimlerinin, bir yandan şiddeti olağanlaştırırken öte yandan yaygınlaştırarak artırdığı söylenilebilir. Bu bağlamda kadına yönelik şiddet, tüm dünyada ve kültürlerde, farklı coğrafi bölge, sosyoekonomik statü ve eğitim düzeyindeki kadınlarda yaygın olarak görülen bir olaydır.

Dünya Sağlık Örgütü'nce 2013 yılında yayınlanan ve küresel, bölgesel düzeyde kadına yönelik şiddetle ilgili verilerin yer aldığ 1 bir raporda, küresel ölçekte tüm kadınların \% 35'inin şiddete maruz kaldığı belirtilmektedir. Raporda; kadına yönelik şiddetin yaygın bir küresel sağlık sorunu olduğu vurgulanmakta ve hayatını kaybeden kadınların \%38'inin şiddet sonucu yakınları tarafından öldürüldüğü belirtilerek şiddete uğrayan kadınların \% 42'sinin de ciddi anlamda yaralandığ 1 ifade edilmektedir. Rapora göre; şiddete uğrayan kadınların 
şiddet mağduru olmayan kadınlara oranla depresyona girme, cinsel hastalığa yakalanma ve alkole yönelme riski 1,5-2 kat daha fazladır (UN Women, 2020; BBC News, 2020)

\section{Türkiye'de Kadına Yönelik Şiddet; Nedenleri ve Önleme Mekanizmaları}

Türkiye'de Kadına Yönelik Şiddet: Kadına yönelik şiddet sorununun yaygınlığına ülkemiz açısından bakıldığında; bu konuda gelişmekte olan ülkelere benzer bir durumda olduğumuz görülmektedir. Ülkemizde göçe dayalı olarak kent nüfusunun kontrolsüz bir şekilde artması, kente uyum problemleri ve yaşanan sosyal sorunların aile yapısında çözülmeler meydana getirmesi, işsizlik ve yoksulluk gibi etkenler, bireylerin psikolojik uyumunu bozmakta ve 2000'li yıllar sonrasında kadına şiddet, aile içi şiddet olaylarında giderek artan oranda bir artış gözlenmektedir. Sonuç olarak her geçen gün, şiddet ve töre cinayetleri nedeniyle pek çok kadın dramatik bir şekilde hayatını kaybetmektedir (Karataş ve Kılıçarslan, 2013, s.111-112)

Aile Sosyal Politikalar Bakanlığı, Kadının Statüsü Genel Müdürlüğü'nce (ASPB, KSGM) yapılan ve 2009 yılında yayımlanan “Türkiye'de Kadına Yönelik Aile İçi Şiddet Araştırması" bulguları, ülkemizde kadına yönelik şiddetin boyutlarını, çeşitlerini, yaygınlığını, yol açtığı etkileri ve nedenlerini ortaya koymaktadır. Araştırmaya göre; ülkemiz genelinde hayatının herhangi bir döneminde fiziksel şiddete maruz kalan kadınların oranı \% 39, duygusal şiddet/istismar yaşayan kadınların oranı ise $\% 44^{\prime}$ tür. Sadece cinsel şiddete maruz kalan kadınların oranı \%15 olup kadınların \% 42'si en az iki şiddetten birini yaşamıştır. Bu bulgular iki şiddetin birlikte yaşandığını göstermektedir. Kent ve kır açısından bakıldığında; fiziksel şiddet oranı kentte \%38 iken, kırda \%43'tür. Araştırma bulguları eğitim düzeyi arttıkça fiziksel ya da cinsel şiddet yaşanma oranının azaldığını göstermektedir. Hiç eğitimi olmayan kadınlarda fiziksel ya da cinsel şiddet yaşanma oranı \% 56 iken lise ve üzeri eğitim düzeyinde bu oran \% 27'ye düşmektedir. Eğitim düzeyi ve yaşanan şiddet arasındaki bağlantıya benzer bir bağlantı, refah düzeyi ve şiddet arasında da vardır. Düşük gelir ve refah düzeyine sahip olan kadınların yarısı şiddete maruz kalmışken, refah düzeyi yüksek olan, 
yaşamını bu koşullara sahip hanelerde sürdüren kadınlarda şiddete maruz kalma oranı \% 29'dur. Bu veriler eğitim ve refah düzeyi arttıkça kadının şiddete karşı çıktığını ve bu davranış biçimini benimsemediğini de ortaya koymaktadır. Boşanmış ve yalnız yaşayan kadınlarda şiddete uğrama yüzdesi korkutucu boyutlardadır. Bu kadınların fiziksel şiddete uğrama oranı \% 73, cinsel şiddete uğrama oranı ise \% 44'tür (KSGM, 2009, s.46-52).

Yine 2014 yılında ASPB, KSGM'nin desteği ile Hacettepe Üniversitesi Nüfus Etütleri Enstitüsü tarafından tüm Türkiye'de gerçekleştirilen Türkiye'de Kadına Yönelik Aile İçi Şiddet Araştırması'na göre, şiddet türleri ve Türkiye'deki yaygınlığına ilişkin veriler şu şekildedir (ASPB ve Hacettepe Üniversitesi, 2015):

1. Fiziksel şiddet; ülke genelinde hayatının herhangi bir döneminde fiziksel şiddete maruz kaldığını belirten kadınların oranı \% 36'dır.

2. Cinsel şiddet; Türkiye genelinde evli kadınların \% 12'si yaşamının herhangi bir döneminde, cinsel şiddete maruz kalmış olup bu kadınların \% 38'i yaşamlarının herhangi bir döneminde fiziksel ve/veya cinsel şiddet yaşamışlardır.

3. Ekonomik şiddet; kadının çalışmasını engelleme, işten ayrılmasına neden olma, kadının gelirini elinden alma ya da ev harcamaları için para vermeme olarak tanımlanan bu şiddet biçimiyle yaşamının herhangi bir döneminde karşı karşıya kalan kadınların oranı \% 30 'dur.

4. Psikolojik şiddet; Türkiye'deki kadınların \% 44'ü yaşamlarının herhangi bir döneminde psikolojik şiddete maruz kalmışlardır.

Şiddete maruz kalan kadınların çoğunluğu, polis, sığınma evi ve jandarmaya başvurabilecekleri konusunda bilgiye sahip olmalarına karşın (ortalama olarak bu üç yapı hakkında \% 80'den fazlası bilgi sahibi) buralara başvurmamaktadırlar. Bunun en temel nedeni olarak kadınlar, başvuru yaptıkları yetkililerce gördükleri şiddetin çok ciddi bir sorun olarak görülmemesini göstermekte ve kadınların \% 81'i polise yaptıkları başvurularda ifadelerinin alınmadığını belirtmektedirler. Bu yaklaşım nedeniyle, yaşadıkları şiddete rağmen kadınların \% 89'u yardım veya destek almak için bu konuda görevli ve de yetkili olan hiçbir yere başvurmamaktadır. Kadına yönelik şiddetle mücadeleden sorumlu olan ve şiddete maruz kalan kadınların çok küçük bir kesiminin (yalnızca 
\%11'inin) başvurduğu bu kurum ve kuruluşlar; kendilerine başvuruda bulunan, iletişime geçen bu kadınlara bile, ihtiyacı olan hizmeti verecek ve gereksinim duydukları desteği sağlayacak şekilde yeterli kapasiteye sahip değillerdir (ASPB, 2015, s.83-176).

TBMM Kadın Erkek Fırsat Eşitliği Komisyonu üyesi N. Tığlı'nın, kadın örgütleri raporları, kadına yönelik saldırı, istismar vb konularda çıkan haberleri inceleyerek hazırladığı ve çeşitli dönemlerde kadına yönelik şiddet, tecavüz, cinayet ve çocuk istismarlarını ortaya koyan "Türkiye'de Kadın Cinayetleri, Cinsel Saldırılar ve Çocuk İstismarı" adlı rapor verileri de kadına şiddetin korkutucu boyutlarını gözler önüne sermektedir. Rapora göre; 2016 yılında 329 kadın öldürülmüş, 350 kadın cinsel şiddete maruz kalmış, 110 kadın da tecavüze uğramıştır. 2017 yılı sonunda öldürülen kadın sayısı bir önceki yıla göre yüzde 24.3 artmış olup bu sayı toplam 409'dur. 2017' de cinsel şiddete uğrayan kadın sayısı 320, tecavüze uğrayan kadın sayısı ise 154'tür. 2018 yılı sonunda öldürülen kadın sayısı bir önceki yıla göre \%7.5 artmış ve 440 olmuştur. 2018'de cinsel şiddet mağduru kadın sayısı 296 olup 140 kadın da tecavüze uğramıştır. 2019 yılında öldürülen kadın sayısı ise toplamda 474 olmuştur. Bir önceki yıla göre artış \% 7.7'dir. 2019' da cinsel saldırıya uğrayan kadın sayısı 166 olup, 96 çocuk da istismara uğramıştır. 2003-2019 arasındaki verilerin değerlendirilmesi; 2003 yılında 83 olan erkekler tarafından öldürülen kadın sayısının, 2016 yılında 329'a, 2018'de 440'a ve 2019'da 474'e çıktığını ve 16 yılda öldürülen kadın sayısında dehşet verici bir artış (\% 471 civarında) olduğunu ortaya koymaktadır. Rapordaki verilere genel olarak bakıldığında; 1 Ocak 2016 ile 31 Aralık 2019 tarihleri arasında 1652 kadın erkekler tarafından öldürülmüş, aynı yıllar içinde en az 1132 kadın cinsel şiddete, 404 kadın tecavüze uğramıştır (Sözcü, 2020; Gurbetçi Giresun, 2020).

2002-2009 arasındaki yedi yıllık sürede erkek şiddeti sonucu öldürülen kadınlarla ilgili olarak o dönemin Adalet Bakanı'na verilen soru önergesine göre; 2002 ile 2009 yılları arasında erkeklerce öldürülen kadın sayısı 4063'tür. 2010-2012 yılları arasında kaç kadının öldürüldüğü sorusuna, sorunun yöneltildiği Aile ve Sosyal Politikalar Bakanı tarafından sorulan dönemde öldürülen kadın sayısının 541 olduğu yanıtı verilmiştir (Sözcü, 2020; Tok, 2020). İki bakanca yapılan açklamalara 2013-2019 arasındaki erkeklerce öldürülen kadınlarla ilgili veriler 
eklendiğinde; 01.01.2002-3.12.2019 tarihleri arasında 18 yılda toplamda erkekler tarafından öldürülen kadın sayısının 7.000'den fazla olduğu görülmektedir (bknz. Tablo 1).

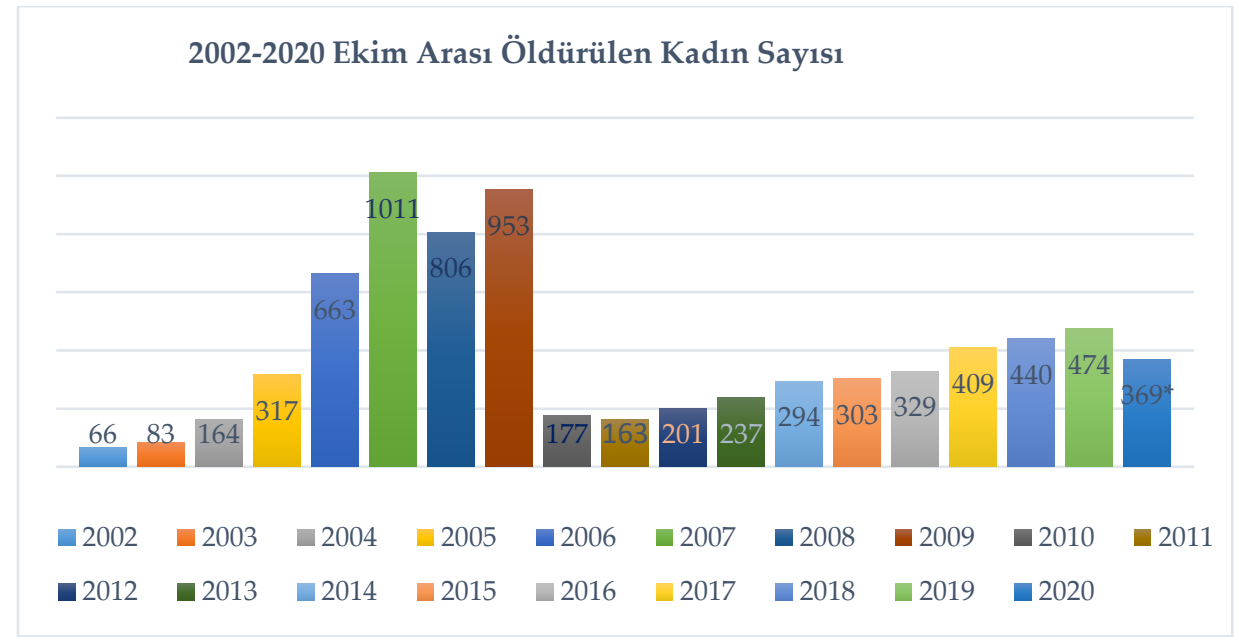

Grafik 1. 2002-2020 Ekim Arası Kadin Cinayetleri Verileri

Kaynak: Gurbetçi Giresun Gazetesi, Ekim 2020 (N. Tiğlı'nın açıklaması

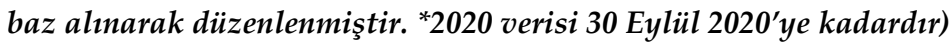

Grafik 1 ve Tablo 1'den de görüleceği üzere; erkeklerce öldürülen kadın sayısı 2002 yılı sonrasında sürekli artmıştır. 2010 ve 2011'de, iki yıllık dönemde düşüş gözlenen kadın cinayetleri, 2012 sonrasında yeniden her yıl belli oranlarda artarak yeniden yükselişe geçmiştir.

Tablo 1. 2002-Ekim 2020 Yilları Arası Öldürülen Kadınlar Tablosu

\begin{tabular}{lll}
\hline Cinayet Yılları & Öldürülen Kadın Sayısı & Açıklamalar \\
\hline 2002 & 66 & \\
2003 & 83 & 01.01.2002 ile 31.12.2009 yıllarını kapsayan veriler, dönemin \\
2004 & 164 & Adalet Bakanı'nın yöneltilen soru önergesine verdiği cevaptan \\
alınmıştır. Bu dönemde öldürülen kadın sayısı, toplam \\
2005 & 317 & 4063 'tür. \\
2006 & 663 & \\
2007 & 1011 & \\
2008 & 806 & \\
2009 & 953 & 01.01.2010-31.12.2012 arasındaki veriler, bu dönemin Aile ve \\
2010 & 177 & Sosyal Politikalar Bakanı'nın soru önergesine verdiği cevaptan \\
2011 & 163 & sağlanmıştır. Bakanca öldürülen kadın \\
2012 & 201 & sayısı 541 olarak belirtilmiştir.
\end{tabular}




\begin{tabular}{lll}
2013 & 237 & \\
2014 & 294 & 01.01.2013-31.12.2019 yılları arasında öldürülen kadınlara \\
2015 & 303 & yönelik -toplamda 2485 kadın- veriler ise "Kadın Cinayetleri, \\
2016 & 329 & Kadın Cinayetlerini Durduracağız Platformu" çalışmalarından, \\
2017 & 409 & yazılı ve görsel medyada bu konuda yer alan haberlerden \\
2018 & 440 & derlenmiştir. \\
2019 & 474 & \\
2020 & 369 & 2020 Eylül ayı sonuna kadardır. \\
Toplam & 7459 & Tablo'da N. Tığlı tarafından derlenen veriler kullanılmıştır. \\
\hline
\end{tabular}

Kaynak: Sözcü, 2020 ve Gurbetçi Giresun, 2020 (Tablo, N. Tiğhl'dan aktarlan veriler kullanılarak oluşturulmuştur.)

1993 'te kurulan ve o günden günümüze, kadınlara uygulanan şiddetle ve bu şiddetin temelindeki toplumsal cinsiyet eşitsizliğiyle mücadeleye yönelik çalışmalar yapan Kadın Dayanışma Vakfı (KDV) Danışma Merkezi kayıtları da kadına yönelik şiddeti ortaya koymaktadır. Bu Vakfın kayıtlarına göre; 2016-2017 yılları arasındaki (1 Ağustos 2016- 31 Temmuz 2017) bir yıllık sürede, şiddete maruz kalarak destek almak için Vakfa başvuran 355 kadının 81'ine (286 kadın) psikolojik şiddet uygulanmıştır. Kadınların karşı karşıya kaldığı psikolojik şiddet; bağırma, hakaret, aşağılama, suçlama, ne giyineceğine, nasıl giyineceğine karışma veya bu konuda baskı yapma, gideceği yerden, görüşeceği kişilere müdahale ederek başkalarıyla olan ilişkisini sınırlama, karşı çıkıldığında yakınlarına zarar vermekle, çocuklarını göstermemek ya da kaçırmakla tehdit etme, vb. biçimlerde gerçekleşmiştir. Derneğin verilerine göre kadınlara erkekler tarafından en fazla psikolojik şiddet uygulanmakla birlikte psikolojik şiddetin yanı sıra ya da yalnızca fiziksel şiddet veya diğer şiddet biçimlerini gördüğünü söyleyenlerin oranı da hiç az değildir. Tablo 2' de bu bir yıllık dönemde derneğe başvuran kadınlara uygulanan şiddet türleri ve oranları verilmektedir.

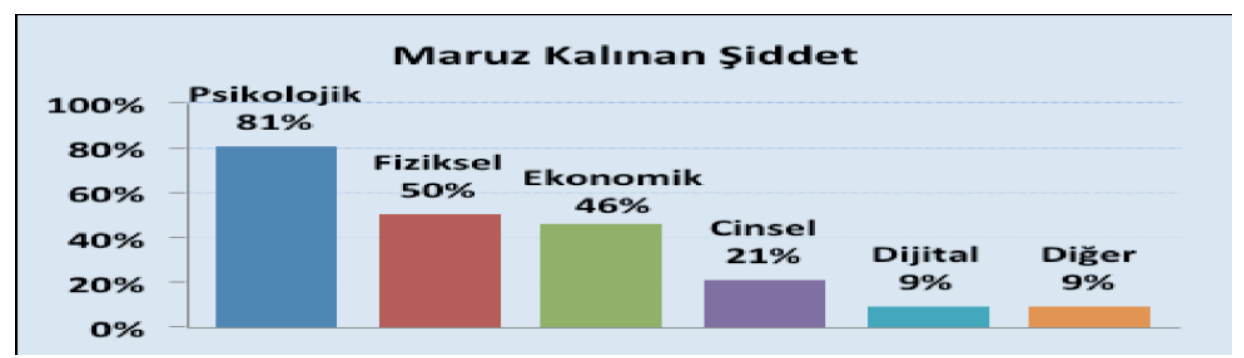

Grafik 2. 2016-2017 Ağustos Arası Farklı Türlerde Kadına Şiddet Verileri 
Kaynak: KDV, 2017, s.7

A. Büyükyılmaz ve Ç. Demir tarafından ülkemizde kadına yönelik aile içi siddeti etkileyen faktörleri ortaya koymak üzere Türkiye İstatistik Kurumu-TÜİK 2008 yılı “Türkiye'de Kadına Yönelik Aile İçi Şiddet Araştırması" ham verileri kullanılanarak yapılan ve bu kapsamda 15-59 yaş arasındaki 2071 kadından elde edilen anket sonuçlarının analiz edildiği araştırma sonuçları; kadınların ve eşlerinin eğitim düzeyinin, düzenli bir işe sahip olup olmamalarının kadına yönelik şiddette belirleyici etmen olduğunu ortaya koymaktadır. Araştırma sonuçlarına göre kadınların fiziksel, cinsel, ya da hem fiziksel hem de cinsel şiddete uğramasında; kadının yaşının, eğitiminin, eşinin bir işinin olması ve eğitim düzeyinin, alkol kullanmasının ve yaşadığı coğrafi bölgenin önemli rolü vardır. Bulgular, kadının ve eşinin eğitim seviyesinin yüksek olmasının, eşinin çalışıyor olmasının ve alkol kullanmamasının, kadına yönelik şiddeti azalttı̆̆ını göstermektedir (Büyükyılmaz ve Demir, 2016, s.445-449).

A. Ediz, Ş. Altan tarafından, İç Anadolu, Karadeniz, Doğu Anadolu ve Marmara Bölgelerinde yaşayan ve herhangi bir nedenle şiddet gören, 200 kadınla yüz yüze görüşülerek elde edilen veriler de en çok şiddet uygulanan kadınların "30-40 yaş" aralığında ve eğitim seviyesi olarak ilkokul-ortaokul düzeyinde eğitimi olan, çoğunlukla evli (\%59) ve de işi olmayan (\%82.8) kadınlar olduğunu göstermektedir. Kadınların eşinden boşanmış olması şiddet görmeyi ortadan kaldırmamaktadır (Ediz ve Altan, 2017, s.402-409).

Kadına Şiddetin Türleri, Nedenleri ve Sonuçları: Şiddet, sıklıkla fiziksel ve psikolojik olarak, bazen de ekonomik ve cinsel biçimdeki uygulamalarla kendini gösteren, kişilerin yaşam kalitelerine ve toplumsal yaşama zarar veren bir olgudur. Tüm toplumlarda mücadele edilmesi gereken sosyal sorunların başında gelen ve mücadele edilmesi için özel politikalar gerektiren şiddetin en fazla uygulandığ 1 kesimlerden biri kadınlardır. Bu bağlamda dünyanın hemen her yerinde olduğu gibi ülkemizde de kadınlar, şiddetin yaratmış olduğu tüm olumsuz sonuçlarla -ki bunlar yukarıda da belirttik psikolojik, fiziksel, sosyal, ekonomik, cinsel olabilir- karşı karşıya kalmaktadır. Bu boyutu ile kadına yönelik 
şiddet, coğrafi, toplumsal, kültürel, dini açıdan sınırı olmayan ya da başka bir ifadeyle sınır aşan küresel bir sorundur. Tüm dünyada olduğu gibi ülkemizde de kadına yönelik şiddet, insanın insan olmaktan kaynaklanan en temel insan haklarının ihlali ve ayrımcılık biçiminde kendini göstermektedir. Eşlerden veya birlikte yaşanılan kişilerden görülen şiddet, bir insan olarak temel haklarının ihlal edilmesinin yanı sıra kadınların fiziksel ve ruhsal sağlıklarını da çok olumsuz etkileyerek onlarda çok daha büyük sorunlara ve olumsuzluklara yol açmaktadır.

Kadına yönelik şiddet, özellikle 1960'lı yıllar sonrasında etkin olmaya başlayan kadın hareketinin çabalarıyla, önlem alınması, politika üretilmesi gereken bir sorunsal olarak toplumların gündemine girmiş ve insan hakları ihlallerinden biri olarak kabul edilmiştir. Bu kabuller sonrasında evrenselleşmiş bir olgu haline gelen kadına şiddeti önlemek üzere dünyada ve ülkemizde birçok dernek, topluluk, devletlerce politikalar üretilmeye başlanmış ve uygulamaya konulmuştur. $\mathrm{Bu}$ politikalarda, kadına şiddet sadece bireysel değil aynı zamanda toplumsal bir sorun olarak değerlendirilmiş ve bu kapsamda devletin, toplumun ilgili tüm organların katılımıyla çözümüne yönelik adımlar atılması, mücadele edilmesi hedeflenmiş, yaptırımlar getirilmiştir. Getirilen yaptırımlarla yapılmak istenen şey toplumsal bir zihniyet değişikliğinin sağlanmasıdır. Ülkemizde kadına yönelik şiddet, 1980'li yılların sonuna doğru ülke gündemine oturan bir konudur. Tüm dünyada olduğu gibi ülkemizde de bu yıllar sonrasında bu alanda birçok yapılanma, düzenleme ya da eylem planı yapılmıştır. Ancak yapılan tüm yasal düzenlemelere karşın ülkemizde kadına yönelik şiddet sorununa çözüm bulunamamış, kadına şiddet her geçen gün artmıştır (Çalışkan ve Çevik, 2018, s.218-220).

Kadına yönelik şiddet denildiğinde genelde akla dayak, yaralama ve cinayet olarak fiziksel şiddet gelse de şiddetin en az fiziksel şiddet kadar önemli, farklı türleri ve boyutları vardır. Fiziksel şiddetin yanı sıra şiddetin ekonomik, psikolojik ve cinsel boyutları da dahil tüm boyutları dikkate alındığında şiddet; kişiye fiziksel zarar vermenin dışında, kişinin psikolojik sağlığını geçici veya kalıcı olarak önemli ölçüde etkileyebilen (Uçar, 2016, s.316-320), kendini gerçekleştirmesini, üretkenliğini engelleyen, özgüvenini ortadan kaldıran bir olgudur. Kadına şiddet uygulamanın amacı da kadını korkutarak, baskılayarak ya da ekonomik 
açıdan güçsüzleştirerek davranışlarını kontrol etmek ve üzerinde hakimiyet kurmaktır. Kadına yönelik şiddetle ilgili çalışmalar, kadınların genelde eş, sevgili gibi yakınlarının saldırılarına maruz kaldıklarını göstermektedir. Kadının en yakınlarından gördüğü tek şiddet, yukarıda da belirtildiği üzere fiziksel şiddet değildir. Kim tarafından ve nasıl uygulanırsa uygulansın fiziksel şiddete diğer şiddet türlerinin birinin ya da hepsinin eşlik etmesi, şiddet mağdurlarında gözlemlenen ve bu konuda araştırmalarda da ifade edilen bir husustur. Bu nedenle kadına şiddet denildiğinde, fiziksel şiddetin yanı sıra sosyal, psikolojik, ekonomik ve cinsel şiddet olguları da mutlaka göz önünde bulundurulmalıdır (Akkaş ve Uyanık, 2016, s.37-38; Arın, 1996, s.305).

Kadına şiddetin birçok nedeni vardır. Bu nedenlerden ilki; eğitim yaşamında başarısızlık, sorunlara çözüm bulma ve sosyal beceri eksikliği, öfke kontrolü yapamama, özgüven eksikliği, yalnızlık, alınganlık, dışlanmışıık, aile içi iletişimsizlik, aşırı baskıcı ya da rahat aile tutumları, tutarsız disiplin, ilgi eksikliği, engellenmişlik duygusu ve sıklıkla engellenme, cezalandırma, aile içi şiddet, istismara uğramak, madde ve alkol bağımlılı̆̆ı, dikkat eksikliği gibi etkenleri olan, psikolojik nedenlerdir (Çiftçi, 2013, s.25). Bir diğer neden biyolojik nedenler olup erkeklik hormonu ve yaşın getirdiği biyolojik değişimlerden kaynaklanmaktadır. Şiddet uygulayanların çoğunlukla erkek olması, saldırgan davranışlarda sadece yaş değil, yaşla birlikte erkeklik hormonlarının da etkili olduğunu göstermektedir. Öte yandan şiddete yönelten biyolojik nedenler arasında kişilik bozuklukları ile bazı ruhsal rahatsızlıkları da saymak gerekmektedir (Öztürk, 2011, s.36).

Kadına yönelik şiddetin toplumsal nedenlerine bakıldığında; geleneksel erkek egemen ve kadını ikinci sınıf vatandaş olarak gören cinsiyetçi tutum, kadın üzerinde hakimiyet kurma ve kadını kontrol etme isteğinin belirleyici olduğu görülmektedir. Öte yandan, toplumda var olan ve kadına şiddeti destekleyen kültürel yapı da hem şiddete yol açan hem de onu besleyen bir etkendir. Bu kültürel yapı nedeniyle şiddet olgusu, nesiller arası kültürel aktarımla insanlık tarihi ile paralel olarak sürmektedir (Okutan, 2007, s.28-29). Şiddete neden olan toplumsal faktörler arasına; geçimsiz aile ortamı, erkek şiddetinin toplumca hafifletici nedenler yaratılarak bir şekilde hoş görülmesi ve bağışlanması, medya araçlarının olumsuz etkisi, kadına karşı önyargılar, sosyal ve 
toplumsal bozukluklar, ekonomik sistem ve eğitimden kaynaklanan problemler, kolayca ateşli silahlara, uyuşturucu maddelere ulaşılması, hoşgörü eksikliği ve tahammülsüzlük, olumsuz arkadaş grupları gibi etkenleri de eklemek gerekmektedir ( Çiftçi, 2013, s.26).

Kadına yönelik şiddetin kadınlar kadar toplumları da derinden etkileyen ciddi sonuçları vardır. Kadına yönelik şiddet kadınlarda, uğradığ 1 şiddetin boyutu ve süresine göre artan oranda kaygı, depresyon, stres, güvensizliğe yol açmaktadır. Şiddete uğrama, kadınlarda intihara meyili ve alkol kullanımını da artırmaktadır. Uyku bozukluğunun yanı sıra her an şiddete uğrayacakmış gibi sürekli tetikte olma duygusuna kapılan kadınlarda, yaşanılan travmaya bağlı olarak psikolojik rahatsızlıklar da artmaktadır (Köse ve Beşer, 2007, s.118). Burada belirtilmesi gereken önemli bir husus da, şiddete maruz kalan kadınların bu durumun toplum içindeki konumuna zarar vereceğini düşünerek yaşadığı şiddeti maskelemesi ve buna bağlı olarak da kendini yıpratmasıdır. Süreç içinde artan yıpranmayla şiddeti maskelemeye devam edemeyen kadın, çevresiyle ilişkilerini kısıtlamakta hatta toplumdan kendini soyutlamaktadır. Bu soyutlama, kadının şiddetin bedeninde ve ruhunda yarattığı her tür ruhsal, fiziksel travmalarla baş başa kalmasına ve tek başına savaşmasına yol açmaktadır. Hem ruhsal hem de fiziksel şiddetin bedeninde bıraktığı izlerle kendilerini toplumdan, sosyal çevreden izole ederek gizlenmeye çalışma, şiddet ortamında yaşayan kadınların geliştirdikleri bir davranış kalıbıdır. Uzun süre şiddete maruz kalan kadınlarda görülen bir diğer davranış biçimi de; kadınların özgüvenlerini yitirerek soysal yaşamdan tamamen uzaklaşmasıdır (Okutan, 2007, s.48-49).

Türkiye'de aile içi şiddetin özel hayatın mahremiyet alanında kalması, birçok kadın tarafından saklanması gereken hassas bir konu olarak görülmesi, ülkemizde kadına şiddetin ve bu şiddetin önlenememesinin en büyük nedenlerindendir. Daha açık ifade etmek gerekirse, kadın kendisine uygulanan şiddete; ekonomik açıdan güçsüz olması, ailenin ekonomik gücünün yetersiz oluşu, örf ve adetler, "kocasıdır sever de döver de" toplumsal anlayışları ve toplumsal cinsiyet rollerine dayalı olarak karşı çıkamamakta ve şiddeti maskelemektedir. Bu nedenlerin yanı sıra kadının ve erkeğin eğitimsizliği, iletişim kurma becerilerinin 
yetersizliği ve cezaların yeterince caydırıcı olmaması gibi etkenler de kadına şiddet önlenememesinin önemli nedenlerindendir.

Gazeteci Sibel Yükler'in tanık/müdahil olduğu ve BBC Türkçe'ye anlattığı aşağıdaki olay, bu saptamaları doğrulayan bir örnektir. Ankara'da yaşayan ve bir akşam evinde otururken dışardan gelen kadın çı̆̆lıklarını duyan Yükler, penceresinden sokağa bakınca, bir erkeğin bir kadını hırpaladığını, olay yerindeki iki küçük çocuğun da aralarında ağlayarak bir taraftan diğer tarafa savrulduklarını görür. O sırada yoldan geçen bir kadının, şiddete uğrayan kadını korumak için koştuğunu fark eden Yükler de "Ne yapıyorsun sen! Bırak kadını" diye bağırarak hemen aşağıya iner. İki kadın araya girerek, şiddet gören kadını ve çocukları erkeğin elinden kurtarırlar. Bunun üzerine erkek üzerlerine yürür, bu arada bu kişinin annesi gelerek araya girer ve oğlunu engeller. Ancak şiddet uygulayan erkeğin annesi, Yükler ve olaya müdahil olan diğer kadına; "Bu aile içi mesele. Lütfen siz karışmayın" diyerek çıkışır ve oğlunu evine göndermeye çalışır. Annenin erkeği eve göndermesine “Bırakalım da kadını öldürsün mü!' diyerek engel olduklarını açılayan Yükler, bu arada eşini döven erkeğin bağırarak eşini öldüreceğini söylerken kendilerini de olaya karıştıkları için "Ayağınızı denk alın" diye tehdit ettiğini belirtmiştir. Bu tehditlere rağmen Yükler polis çağırmış ve aile içi şiddet hatlarına olayla ilgili ihbarda bulunmuştur. Ancak akşam emniyetten aranan Yükler'e; "yapılan ihbar ve şikayetlere bağlı olarak polislerin eve gittiği ancak kapıyı açan kişinin şikayetçi değiliz dediği için bir şey yapılamadığı" bilgisi verilmiştir (Şimşek 2019).

Kadına Yönelik Şiddetle Mücadele Araçları: Türkiye'deki kadına yönelik şiddetle mücadelede kullanılan yasal/hukuki araçları ulusal ve uluslararası araçları olarak ikiye ayırarak inceleyebiliriz.

Ulusal düzeyde baktığımızda; ülkemizde, 1982 Anayasası'nda “kişinin temel hak ve özgürlüklerini korumak, onların madden ve manen gelişmesi için gerekli koşulları hazırlamak, sağlıklı ve dengeli bir çevrede yaşamalarını sağlamak devletin görevidir. Anayasa'nın 10 ve 12 . maddeleri, ülkemizde kadınların erkeklerle eşit haklara sahip ve özgür bireyler olduğunu ortaya koymakta ve kadınların yaşaması, gelişmesi, erkeklerle eşit bireyler olarak toplum yaşamında yer alması için gereken ortamı sağlamanın da devletin görev olduğunu açıkça ifade etmektedir 
(Anayasa, 1982). Kamu için emredici özel sektör için yönlendirici olup bu konumu ile uyulma zorunluğu kalkınma planlarında da kadınlarla ilgili öncelikler yer almaktadır. 10. Kalkınma Planı'nda; kadınlara erkeklerle istihdamda, karar alma mekanizmalarına daha aktif katılmada fırsatlar sunularak kadın-erkek fırsat eşitliğinin sağlanması, kadına şiddetin önlenmesi, eğitim ve sağlıkla ilgili iyileştirmelerin sağlanması ve bu konudaki uygulamaların etkinliğinin artırılması gerektiği vurgulanmaktadır. Plan'ın Politikalar kısmında da yine "Kadınların karar alma mekanizmalarında daha fazla yer almalarının ve bu alanda daha etkin olmalarının sağlanacağı, istihdamının artırılacağı, eğitim ve beceri düzeylerinin yükseltileceği" söylenmektedir. Planda, özellikle erken çocukluktan başlayacak örgün ve yaygın eğitimler yoluyla toplumsal bilinç düzeyi yükseltilerek, kadına yönelik ayrımcılığın ortadan kaldırılması ve şiddetin önlenmesi hedeflenmektedir (Kalkınma Bakanlığı, 2013, s.40-41). Benzer hedefler 11. Kalkınma Planı'nında da yer almaktadır. Planın hedef ve politikalarının yer aldığı 2 . Bölümünde "Ailenin Güçlendirilmesi ve Kadın" şeklinde iki ayrı başlık altında; aile içi şiddet, ihmal ve istismarın ile kadına yönelik şiddetin, erken yaşta zorla evliliklerin, her türlü istismarın önlenmesi; toplumsal farkındalığın, koruyucu-önleyici hizmet etkinliği ve kapasitesinin artırılması, şiddete yol açan olumsuz tutum ve davranışların ortadan kaldırılması, bu konudaki bilinçlenmenin artırılması için; örgün ve yaygın eğitim faaliyetleri düzenleneceğinden, bu konudaki düzenlemelerin etkin uygulanması için çalışmalar yapılacağından ve kamu kuruluşları da dahil olmak üzere farklı hedef gruplarına yönelik eğitim, farkındalık artırma çalışmalarına devam edileceğinden söz edilmektedir (Cumhurbaşkanlığ1 Strateji ve Bütçe Başkanlığı, 2019, s.150-152).

İç hukukumuzda kadına yönelik şiddetin doğrudan ele alınıp düzenlendiği ilk yasal düzenleme, 1998 yılında yürürlüğe giren 4320 Sayılı Ailenin Korunması Hakkında Kanundur. Ancak bu Kanun, getirdiği düzenlemelerin uluslararası hukuk kurallarına ve uluslararası içtihatlara uygun olmadığı, kadınları şiddetten korumak için yeterli araç ve önlemleri içermediği ve sadece resmi olarak evli kadınları kapsadığı gibi sebeplerle hem kadın hakları alanında çalışan hukukçular hem de kadın hakları savunucuları tarafından eleştirilmiş ve değiştirilmesi istenmiştir. Bu eleştiriler ve talepler kapsamında, uluslararası hukuktaki 
gelişmeleri de dikkate alacak şekilde yeni bir yasa hazırlanmış ve 2012 yılında 6284 Sayılı Ailenin Korunması ve Kadına Yönelik Şiddetin Önlenmesine Dair Kanun, 2013 yılında ise bu Kanunun uygulama yönetmeliği yürürlüğe girmiştir. 6284 Sayılı Kanun, 2011 de onaylayıp Anayasa'nın 90. maddesi kapsamında bir uygun bulma kanunu ile iç hukukumuzun parçası yaptı̆̆ımız ve 20 Mart 2021'de yayımlanan 9 No'lu Cumhurbaşkanlığı Kararnamesi-CBK ile çıktığımızı ilan ettiğimiz (CBK ile çıkılabilir mi çıkılamaz mı tartışmaları ile sözleşmeden çıkılmasına tepkilerin hala sürdüğü) İstanbul Sözleşmesi diye bilinen Kadına Yönelik Şiddet ve Ev İçi Şiddetin Önlenmesine Dair Avrupa Konseyi Sözleşmesi ile büyük oranda uyumludur. Kanunda getirilen düzenlemelerle, kadınların hem şiddet tehdidi altında oldukları dönemde alınacak önlemler hem de şiddete uğradıktan sonra başvurabilecekleri araçlar düzenlenmiştir. Kanun ile 7 gün 24 saat esasına göre çalışacak şiddet önleme ve izleme merkezleri kurulması öngörülmektedir. Şiddet Önleme ve İzleme Merkezleri ya da kısa adıyla ŞÖNIMM'ler, Aile, Çalışma ve Sosyal Hizmetler Bakanlığı (AÇSHB)'na bağlı olarak 2012 yılında kurulmuş ve bu Kanun kapsamındaki faaliyetlerine başlamışlardır.

Ülkemizde, hem bu konuda mevcut yasaların hem de altına imza koyduğumuz Birleşmiş Milletler Kadınlara Karşı Her Türlü Ayrımcllığın Önlenmesi Sözleşmesi (CEDAW) başta olmak üzere; Avrupa Sosyal Şartı, Çocuk Hakları Sözleşmesi gibi pek çok sözleşme ile Dünya Kadın Konferansı Eylem Planları gibi belgelerin gereği olarak kadınlarla ilgili pek çok çalışma yapılmaktadır. Bu çalışmalardan sorumlu olan bakanlık o zamanki adıyla Aile, Çalışma ve Sosyal Hizmetler Bakanlığı'dır (21 Nisan 2021'de yeniden iki ayrı bakanlığa dönüştürüldü). Kanun ve imza koyduğumuz uluslararası belgelerin kapsamına giren tüm çalışmalar, bu Bakanlıkça koordine edilerek, gerekli kurum kuruluşlarla işbirliği yapılarak yürütülmektedir. Bu kapsamda gerçekleştirilen ve 2006 sonrasında yayınlanan genelge sonrasında başlatılan ve dönemsel olarak sürdürülen çalışmalardan biri, "Kadına Yönelik Şiddetin Önlenmesi Eylem Planları"dır. Bakanlıkça, bu kapsamda en son 2016-2020 yıllarını kapsayan ve kadına şiddetin tüm ilgili tarafların katılımıyla önlenebilmesini amaçlayan "Kadına Şiddetle Mücadele Ulusal Eylem Planı" hazırlanmıştır. Bu planın amacı "Ülkemizde kadına yönelik her türlü şiddetin, ev içi şiddetin önlenmesi; şiddet mağdurlarmm etkin bir biçimde 
korunması için tüm tarafların işbirliğiyle gerekli önlemlerin alınması ve uygulanması" olarak belirlenmiştir. Bu amacı gerçekleştirmek üzere 10. Planda belirlenen hedefleri de kapsayan; "Mevzuat düzenlemeleri, Farkındalık yaratma ve anlayış değişimi, Koruyucu ve önleyici hizmet sunumu ve şiddetten zarar görenlerin güçlenmesi, Sağlik hizmetlerinin düzenlenmesi ve uygulanması, Kurum, kuruşlararası işbirliği ve politika geliştirme" başlıklı beş hedef altında birçok eylem planlanmıştır (KSGM, 2016, s.36-76). Bakanlık yapılanmasında tüm bu çalışmaları yürütmekten sorumlu bir genel müdürlük yapılanması, Kadının Statüsü Genel Müdürlüğ̈ü, yer almakta, ayrıca aile ve çocuk konularındaki çalışmaları yürütmek üzere de genel müdürlükler bulunmaktadır (Aile, Çalışma ve Sosyal Hizmetler Bakanlığı, 2019, s.2-6).

Bakanlıkça hazırlanan ve 2020-2021 yıllarını kapsayan Kadına Yönelik Şiddetle Mücadele Koordinasyon Planı'nda 2021-2025 yıllarını kapsayacak "Kadına Yönelik Şiddetle Mücadele 4. Ulusal Eylem Planı"nın uluslararası ve ulusal mevzuatımızın öncelikleri ve ilgili paydaşların katkı ve katılımları ile 2020 yılında hazırlanacağı belirtilmektedir. Ancak söz konusu plan Bakanlık resmi web sitesinde yer almamaktadır. Sitede 2013-2023 yıllarına yönelik olarak hazırlanmış Kadının Güçlenmesi Strateji Belgesi ve Eylem Planı yer almaktadır. Bu planda; eğitim, sağlık, ekonomi, karar alma mekanizmalarına katılım, medya başlıkları altında beş temel politika ekseninde mevcut durum, temel amaç, hedefler, stratejiler ve faaliyetler düzenlenmiştir. Planda bu beş eksende belirlenen beş temel amaç altında 21 hedef, 21 strateji ve 126 faliyete yer verilmektedir. Ancak hiçbir başlık altında kadına şiddet konusu temel hedef veya stratejisi olarak tanımlanmamış olup sadece Eğitim ve Ekonomi politika başlıklarındaki iki stratejinin alt strateji olarak iki strateji tanımlanmıştır. Bu kapsamda; "Eğitim” başlığı altındaki "Kız çocuklarımın ve kadınların eğitime kayıt, devam ve tamamlama oranlarının arttırılması" stratejisinin alt stratejsii "Kuran kurslar ile yaygın eğitim kapsamındaki kursların programlarına kadının insan hakları, kadına yönelik şiddet ve değerler eğitimi konuları entegre edilecektir" ve "Ekonomi" başlı̆̆1 altında "Özel politika gerektiren kadınların ekonomik hayata katılmaları konusunda çalışmaların arttırılması" stratejisinin alt stratejsi olarak "Şiddet mă̆duru kadınların işgücü piyasalarına girişlerinin kolaylaştırılması için ilgili 
ŞÖNIM/Kadın Konukevlerinde kurumsal hizmet modeli geliştirilecektir."denilmektedir (AÇSHB, 2018, s.116-209).

Yukarıda yer alan bilgiler bize; ülkemizde kadın, aile ve çocukla ilgili olarak, yasalarca verilen yetki ve sorumlulukları yerine getirecek, bakanlıktan sivil toplum kuruluşlarına gerekli yapılanmaların ve anayasadan başlayarak, kanundan yönetmeliğe gereken yasal düzenlemelerin bulunduğunu göstermektedir. Bu noktada kanımızca sorgulanması gereken, yasal olarak mevcut olan birçok belge ve düzenlemelerde yer alan ayrımcilıktan uzak ve özgür olma durumunun ilgili yapılarca ve tüm tarafların katılımını sağlayarak uygulamaya ne ölçüde geçirilebildiği ve mevcut düzenlemelerin toplumsal açıdan özgür olmayı sağlayıp sağlayamadığıdır. Çünkü 6284 Sayılı Kanunun etkili bir şekilde uygulanmadığını, Bakanlıkça, üniversiteler, akademisyenlerce yapılan araştırmalar, bu alanda çalışan sivil toplum kuruluşlarının raporları (örn. Kadın Danışma Merkezi'nce başvuran kadınlarla ilgili olarak verilen bilgiler), basına yansıyan haberler ve Avrupa İnsan Hakları Mahkemesi'nin (AİHM) kararları açıç̧a ortaya koymaktadır. Öte yandan şiddete maruz kalan kadınların talep ettikleri tüm hizmetleri, aynı yerde, tek seferde alması anlayışı temelinde yapılandırılan ve bu nedenle de tek kapı sistemi olarak adlandırılan ŞÖNİM'ler de sundukları hizmetler ve uygulamalarıyla eleştirilmektedir. Bu eleştirilerde; buradaki personelin ve ŞÖNİM'lerin nicelik ve nitelik olarak yetersizliği dile getirilmekte, hükümetin kadına yönelik şiddetle ilgili bütünlüklü ve istikrarlı bir politikası olmadığı için merkezlerin de planlanan işlevini yerine getiremediği ve böylece şiddete maruz bırakılan kadınların hukuk süreçlerinde ikincil travmalar yaşamasına neden olunduğu ileri sürülmektedir (Kadın Dayanışma Vakfı, 2017, s.12-13).

\section{Sonuç ve Değerlendirme}

Kentlileşme; çağdaş yaşamın gerektirdiği tüm zihinsel ve davranışsal değişikliği içeren ve buna bağlı anlayışlarla biçimlenen toplumsal yaşamı içinde barındıran bir yaşam biçimidir. Ancak bu konudaki araştırmalar, eylem olarak bir şeylerin yapılmasının, bireylerin zihinsel olarak da değiştiği ve yeni bir anlayışı içselleştirdiği anlamına gelmediğini ortaya koymaktadır. Bir kentte yaşamanın zorunlu sonuçları olan bazı 
davranışları yerine getirdiği halde bunları içselleştiremeyen insan, gelişmeye dirençli ve kentte kentlileşememiş kümelerin ortaya çıkmasına yol açmaktadır. Kente yalnızca fiziken dahil olan bireylerin, sosyokültürel ve sosyo-psikolojik açıdan uyum sağlayamamasının sonucu ise kente yabancılaşması, kendi kültürüyle yaşadığı gettolarda ait olduğu cemaat kültürü ve kent kültürü arasında kalarak uyum gösterememesi, şiddet eğiliminin artmasından suça yönelmeye kadar birçok toplumsal sorunun doğmasına neden olmasıdır. Ülkemizde iç ve dış göçlerin etkisiyle ortaya çıkan kentleşme sürecinin sonucu, kentlerin bir kısmının kentlilik ruhuna sahip olmayan, kendini oraya ait hissetmeyen, yabancılaşmış bireylerle dolmasıdır. İşsizlik, kayıt dışı ekonomi ve istihdam, nitelikli işgücü, insan sermayesi, eğitim, sağlık ve altyapı hizmetleri yetersizliği gibi faktörlere dayalı olarak artan kent yoksulluğu, şiddet de bu yabancılaşmanın sonuçlarındandır.

Şiddet, kişinin değer yargıların zedeleyen, sahip olduğu niteliklerini, kendine güvenini ve ruhsal yapısını bozucu etki yapan bir olgudur. Bir toplumun neredeyse yarısı kadınlardan oluşur ve kadının gelecek nesillerin yetişmesinde anahtar rolü vardır. Bu nedenle kadınların önemli bir kısmının şiddete uğraması sadece bireysel değil aynı zamanda aile ve toplum açısından da olumsuzluklara yol açan önemli bir sorundur. Göçe dayalı olarak ortaya çıkan şiddet olgusunda; ekonomik refahın sağlanması, bölgesel gelişme farklılıkları ve gelir dağılımı adaletsizliklerinin kaldırılmasına yönelik çalışmalarla göçün kontrol altına alınması; ayrıca, kente gelenlerin birey ve aile olarak kendilerini kente ait hissetmelerini sağlamalarına yönelik ekonomik ve sosyal açıdan güçlendirilmesinin sağlanması gerekmektedir. Ekonomik ve sosyal açıdan yetkinlik özellikle erkekler için şiddete yönelmede önemli bir etken olan özgüven ve güç kaybı duygusunun ortadan kalkmasına yardımcı olacaktır. Öte yandan kentlilik bilincine sahip ve kendini kente ait hisseden bireyler; sadece fiziken kentte yaşamayıp ayn zamanda kentte olup bitenlerle ilgilenerek, kentin bir parçası olduğunun farkında olarak, kenti için sorumluluk alacak, kente özgü tutum ve davranışları daha kolay sergileyecektir (Keskin, Sağocak ve Vural, 2015, s.28).

Aile en küçük toplumsal birimdir. Aileyi korumak ve güçlendirmek üzere ekonomik ve sosyal açıdan alınan önlemler ve bu konudaki farkındalığı artıracak çalışmalar, hem bireysel ilişkileri sağlıklı kılacak 
hem de toplumun temeli olan ailenin sağlıklı ilişkiler gerçekleştirmesini ve yürütmesini sağlayacaktır. Nihai olarak bu durum, çekirdeği ailelerden oluşan toplumumuzun da sağlam temellere dayalı güçlü bir toplum olmasına katkı sağlayacaktır (Kocacık ve Çağlayandereli, 2009, s.41-42).

Ülkemizde kadına şiddetle mücadelede yardımcı olması amacıyla oluşturulan destek kuruluşlarının daha ulaşılabilir ve bu yapılara başvurarak sonuç almanın daha etkin hale getirilmesine ihtiyaç vardır. Çünkü bu araçlardan faydalanmak üzere bir adım atan şiddet mağduru kadınlar, hemen hemen başvurdukları her kurum, kuruluşta destek almak yerine ikincil mağduriyetler yaşamaktadır. Bu nedenle şiddete maruz kalan kadınlara sunulan destek hizmetlerinin sayıca arttırılmasından daha da önemli olan bu hizmetlerin niteliği ve onların beklentilerini karşılamasıdır. Bu açıdan kadın sığınma evlerinin yalnızca kadınlara barınma sağlayan yerler olarak düzenlenmemesi ve bu konudaki mevcut yaklaşımın değiştirilmesi gerekmektedir. Bu çerçevede bu mekanlarda kadını manen ve madden güçlendirecek şekilde hizmet sunabilecek bir altyapı oluşturulmalı ve verilen desteklerle kadına kendi ayakları üzerinde durarak şiddetten uzak bir yaşam kurması sağlanmalıdır. Öte yandan kadına yönelik şiddetin yalnızca adli vaka olarak görülmemesi, şiddete uğrayan kadınlara kolluk güçleri ve adli birimlere başvurmak ya da bir sığınağa yerleşmek dışında alternatifler sunan bir destek mekanizmalarının da uygulamaya sokulması gerekmektedir. Hafifletici nedenler ileri sürülerek kadına yönelik şiddetin cezasız kalmasının önüne geçilmesi de kadına şiddetin önlemesinde atılması gereken adımlardan biridir.

Ulusal mevzuatın yanı sıra ülkemize yükümlülükler getiren uluslararası mevzuatların da gereklerinin yerine getirilmesi içinde daha kararlı olunmalı ve bunların uygulamaya sokulmasına yönelik mekanizmalar kurulmalıdır. Bu kapsamda aile içi şiddet ve kadına yönelik şiddetin önlenmesi için düzenlenen ve İstanbul'da imzaya açılan, ülkemizin de ilk imzacılarından biri olduğu İstanbul Sözleşmesi'den bir başka ifadeyle Avrupa Konseyi Sözleşmesi'nden ayrılma kararı tekrar gözden geçirilmeli ve tarafı olduğumuz BM “Kadınlara Karşı Ayrımcılı̆̆ın Önlenmesi-CEDAW'ın gereklerini yerine getirmek ve onun getirdiği standartlara ulaşabilmek adına da öncelikle şunlar yapılmalıdır: i. Ülkemizde kadınlara yönelik her türlü ayrımcılığın kaldırılması 
sağlanmalı ve bu konudaki düzenlemeler sözde veya kağıt üzerinde kalmadan uygulanmalı, ii. Kadının toplumsal rolü yeni bir anlayışla tanımlanmalı ve medyadan eğitime tüm araçlarla benimsenmesi için çalışmalar yapılmalı, iii. Geleneksel toplumsal cinsiyet rollerinin ortadan kaldırılması için harekete geçilmeli, iv. Kadına şiddetin ekonomik ve sosyal boyutları dikkate alınarak kentsel, toplumsal gelişmeyi engelleyici bir sorun alanı olarak ele alınmalı ve bu kapsamdaki politikalarla entegrasyonu sağlanmalı, v. Kadın işgücü, emeğinin ekonomiye dahil edilmesi için "Kalkınma Ajansları"ndan yararlanılmalıdır.

Kadın ve aile içi şiddet konusunun çözümü ve bu konuda bilinçli duyarlı olunması için toplumda farkındalık yaratılması, eğitimli nesiller yetiştirilmesi önemlidir. Bu açıdan da ana sınıfından itibaren başlayacak eğitimlerin yanı sıra kamu yönetimi bölümleri ve hukuk fakültelerinin ders programlarına konulacak kadın, çocuk hakları, insan hakları, toplumsal cinsiyet ayrımcllı̆̆, şiddet, cinsiyet eşitliğine yönelik derslerle bu konularda duyarlı kamu yöneticileri, hakim, savcı ve avukatların yetiştirilmesi sağlanmalıdır. İlk öğretimde cinsiyet ayrımcılığını destekleyen, kadını belirli kalıplara sokan yazılı ve görsel ders materyalleri gözden geçirilerek bu ayrımcılığı genç beyinlerden kaldıracak şekilde yeniden düzenlenmelidir. Eğitim konusunda yapılması gereken bir diğer konu da aile bireylerinin eğitimidir. Bu eğitimlerle bireylerde vicdan, etik ve ahlaki değerlerin yerleştirilmesi sağlanmalıdır. Özellikle kent kültüründen uzak yaşamların sürüldügü gecekondu bölgelerinde -başta yerel yönetimler olmak üzere bu konuyla ilgili sivil toplum kuruluşları, üniversitelerle işbirliği yapılarak- kadınları sosyoekonomik açıdan güçlendirecek, özgüven kazanmalarını sağlayacak üretime yönelik tesislerinin kurulması sağlanmalı, kadın girişimciliği desteklenmelidir.

Türk toplumu açısından önemli olan ve değiştirilmesi gereken bir nokta da çocukların yetiştirilmesinde yaygın olan ve genelin benimsediği kız ve erkek çocuklara yönelik ayrımcı uygulamalardır. Toplumsal kültürümüzde, erkek çocuğa sahip olmak çok önemli olarak görülmektedir. Rol davranışlar oluşturulurken, kız çocuklarına evde, erkek çocuklarına ise ev dişında roller yüklenmekte, bunun sonucunda kızlar kısıtlanırken, erkek çocukları özgür olarak yetiştirilmektedir. Bu bağlamda, sürekli olarak yinelenen, "babasıdır, kocasıdır, erkektir sever 
de döver de" gibi söylemlerle, toplumsal hayatta, kadına "gerektiğinde" şiddet uygulamayı normalleştiren, kadının namusunu kendi namusu olarak gören ataerkil, erkek egemen anlayışlar değişmeli, kadınların ve erkeklerin eşit haklara sahip bireyler olarak yetiştirilmesi ve bu halleri ile toplum yaşamında yer almaları sağlanmalıdır.

Yukarıda da belirtildiği üzere aile bireylerinin ekonomik güçlerinin, refah düzeylerinin artırılması ya da dış etkenlerin yol açtığı göçlerin toplumsal sorunlara yol açmaması için önlemler alınarak kır-kent farklılıklarını dikkate alacak ve ekonomik ve sosyal açıdan beklentilere cevap verecek, şekilde dengeli bir biçimde gerçekleşmesinin sağlanması, kentlileşememenin yarattı̆̆1 şiddet, yoksulluk ve varoş kültürünün etkisinin azaltılması ve süreç içinde yok edilmesi açısından dikkate alınması gereken hususlardır. Sonuç olarak projeden eğitime, eylem planlarına toplumun tüm kesimlerinin beklentilerine karşılık verecek ve onların katılımıyla gerçekleşecek ekonomik, sosyal, kültürel tedbirler ve eğitimlerle, aslında kentleşme sürecini iyi yönetememenin bir sonucu olan ve bu açıdan Prof. Sancar tarafından "kolektif suç" olarak tanımlanan bu durumun kanımızca çözümü de toplumun bütüncül bir şekilde karşı çıkması ile sağlanabilecektir. 


\section{EXTENDED ABSTRACT}

\section{Non-Urbanization and Social Dynamics of Violence against Women}

Esmeray Alacadağl1

Bayburt University

Migration is the movement of people voluntarily or compulsorily within the country, generally from rural to urban, or from one country to another, based on various reasons. One of the results of this movement is urbanization. Urbanization occurs through not only the employment of people living in the city in jobs specific to the city but also adaptation of social and cultural behavior patterns and value judgments that are unique to the city. When the economic and social transformation of the masses migrating from the countryside to the city is not achieved, individuals can become alienated from the city and cause many problems in terms of society and the city (Es and Ateş, 2004, p.215; Keleş, 2016, p.22-31). Some of these problems are turning to violence and crime due to increasing reactivity based on socio-spatial divisions (Parlak, 2008, p. 67) in the form of communities, ghettos.

Violence is a phenomenon that affects people physically, emotionally and socially. Those most affected by violence are; women, children, the elderly and the disabled. There are many reasons for violence against women based on economic, social and psychological factors. As an example of these reasons; Factors such as failure in education, inability to control anger, lack of self-confidence, exclusion, lack of communication within the family, lack of interest, feeling of inhibition, domestic violence, being abused, substance and alcohol addiction, and lack of attention can be given (Çiftçi, 2013, p.25). On the other hand, personality disorders and some mental disorders (Öztürk, 2011, p. 36) and the traditional maledominated, sexist attitude that sees women as second-class citizens, the desire to dominate and control women, the incompatible family environment, the cultural structure that supports violence against women and the tolerance of male violence is also a determining factor in this regard and fosters violence (Okutan, 2007, pp. 28-29; Çiftçi, 2013, p. 26). 
After the 2000s, there has been an increasing increase in violence against women and domestic violence in our country. The researches show that factors such as unemployment and poverty play a role due to uncontrolled increase in the urban population based on immigration and dissolution in the family structure due to the problems of adaptation to the city, (Karataş and Kılıçarslan, 2013, pp.111-112).

Urbanization in Turkey took place in the form of one-way migration from rural to urban areas, and could not develop in a way that would be the driving force of development by providing the development of industry and employment of labor force. In this context, economically, the urbanization of our country has led to unemployment, imbalance in sectoral and interregional development, congestion in infrastructure services, occupation of public lands with shelters called slums Socially, the ones that emerge as a result of urbanization are; inequality in income distribution, social stratification, increase in classification, ghettoization, cultural change problems, disintegration and discord in social life, an increase in tendency towards crime and violence (Sezal, 1992, pp.74-78; Parlak, 2008, p. 67).

According to the "Research on Domestic Violence Against Women in Turkey" conducted by Hacettepe University in 2014 (ASPB, 2015); in Turkey, the rate of women who have been exposed to physical violence at any point in their lives is $36 \%$. Throughout Turkey, married women at any stage of her life, were exposed: $12 \%$ to sexual violence, $30 \%$ to economic violence, and $44 \%$ to psychological violence. The majority of women who have been subjected to violence do not apply to authorities such as the police, shelters and gendarmerie because they do not see the violence they experience as a very serious problem. The number of women applying to institutions and organizations responsible for combating violence against women is only $11 \%$. However, the fact that these institutions are not in a position to provide the service and support that the applicant women need is another problem (ASPB, 2015, pp.83-176).

According to the "Female Murders, Sexual Assaults and Child Abuse in Turkey" report data of N. Tiğll, member of the GNAT Equal Opportunity Commission; The number of women killed by men increased from 83 in 2003 to 328 in 2016, 440 in 2018 and 474 in 2019. Between January 1, 2016 and December 31, 2019, 1652 women were killed by men, 
at least 1132 women were subjected to sexual violence and 404 women were raped in the same years (Sözcü, 2020).

Turkish society is a patriarchal society. In this patriarchal family structure, the majority of women are brought up with a perception of "male child" in which men are superior to women, and with an understanding of obedience to men. For this reason, domestic violence in Turkey remains in the privacy of private life and is considered by many women as a sensitive issue that should be hidden. Women cannot oppose the violence against herself and masks violence due to being economically weak, customs and traditions, social understandings of "her husband loves but also beats her" and social gender roles. Factors such as the lack of education of women and men, inadequacy of communication skills and the inadequacy of punishments are among the important reasons why violence against women cannot be prevented.

Economic welfare, controlling immigration; strengthening those who come to the city need to be economically and socially as individuals and families should be ensured in the phenomenon of violence based on immigration. Economic and social competence will help to eliminate the feeling of loss of self-confidence and power, which is an important factor in turning to violence, especially for men. On the other hand, individuals who have an urban consciousness and feel that they belong to the city, In addition to living in the city physically, will take responsibility for his city by taking care of what is happening in the city, and will more easily exhibit city-specific attitudes and behaviors (Keskin, Sağocak, \& Vural, 2015, p. 28). Another point that is important for Turkish society and needs to be changed is the discriminatory practices against girls and boys. Taking measures to increase the economic power and welfare of family members are important issues in terms of reducing the violence, poverty and slum culture created by the lack of urbanization.

\section{Kaynakça / References}

Aile, Çalışma ve Sosyal Hizmetler Bakanlığı. (2019). 2018 yılı faaliyet raporu, Ankara.

Aile, Çalışma ve Sosyal Hizmetler Bakanlığı. (2018). Kadının güçlenmesi strateji belgesi ve eylem planı 2018-2023. Kadının Statüsü Genel Müdürlüğü, Ankara. 
Aile Sosyal Politikalar Bakanlığı-ASPB ve Hacettepe Üniversitesi. (2015).

Türkiye'de kadına yönelik aile içi şiddet araştırması raporu, 2015. Ankara: Elma Teknik Basım Matbaacilık.

Akkaş, İ. ve Uyanık, Z. (2016). Kadına yönelik şiddet. Nevş̧ehir Hacı Bektaş BektaşVeli Üniversitesi Sosyal Bilimler Enstitüsü Dergisi, 6(1), 32-42.

Arın, M. C. (1996). Kadına yönelik şiddet. Cogito, (6-7), 305-312.

Alacadağlı, E. (2020). Çocuk yoksulluğu. Ş. Dilli (Der.), Türkiyede çocuk olmak içinde (s.169-197). Ankara: Pegem Akademi.

Anayasa (1982). Yeni Anayasa 1982. İstanbul: Yasa Yayınları.

Bayındırlık ve İskan Bakanlığı. (2009). Kentleşme Şûrası 2009. Kentsel yoksulluk, göç ve sosyal politikalar raporu, Ankara.

BBC News (2020). DSÖ: Her üç kadından biri şiddet mağduru. 10.01.2020 tarihinde

https://www.bbc.com/turkce/haberler/2013/06/130620kadina siddet adresinden erişildi.

Büyükyılmaz A. ve Demir Ç. (2016). Türkiye'de kadına yönelik aile içi şiddetin belirleyenleri: multinomial logit model yaklaşımı". Ege Akademik Bakış Dergisi, 16(3), 443-45.

Cumhurbaşkanlığı Strateji ve Bütçe Başkanlığı (2019). On birinci kalkınma planı (2019-2023). Ankara.

Çalışkan, H. ve Çevik, İ. E. (2018). Kadına yönelik şiddetin belirleyicileri: Türkiye örneği. Balkan Sosyal Bilimler Dergisi, 7(14), 218-233.

Çiftçi, F. (2013). Türkiye'de kadına yönelik aile içi şiddet ve kadın sığınmaevleri. Yayımlanmamış Yüksek Lisans Tezi. Kırıkkale Üniversitesi, Sosyal Bilimler Enstitüsü, Kırıkkale.

Ediz, A. ve Altan, Ş. (2017). Türkiye'de kadına yönelik şiddet üzerine bir alan araştırması. TBB Dergisi, 338-406.

Es, M. ve Ateş, H. 2004). Kentlileşme ve göç: sorunlar ve çözüm önerileri. Sosyal Siyaset Konferanslarn Dergisi, 48, 205-247.

Gurbetçi Giresun Gazetesi, (2020). 12.08.2021 tarihinde https://gurbetcigiresun.com.tr/necat-tigli-kadin-cinayetleri-raporuhazirladi-34066-haberi adresinden erişildi.

Gül, H. ve S. Gül, S. (2008.). Yoksulluk ve yoksulluk kültürü tartışmaları. Nurgün Oktik (Der.), Türkiye'de Yoksulluk Çalışmaları içinde (s.57-96). İzmir: Yakın Yayınları.

Güneş, Z. (2009). Türkiye'de yoksulluk araştırmaları: 1990 sonrası çalışmaların bibliyografik analizi. Yayımlanmamış Yüksek Lisans Tezi. Marmara 
Üniversitesi, Türkiyat Araştırmaları Enstitüsü Bilgi ve Belge Yönetimi Anabilim Dalı, İstanbul.

Kadının Statüsü Genel Müdürlüğü, (2009). Türkiye'de kadına yönelik aile içi şiddet araştırması raporu. Ankara: Aile Sosyal Politikalar Bakanlı̆̆ Yayını.

Kadının Statüsü Genel Müdürlüğü-KSGM. (2016). Kadına yönelik şiddetle mücadele (2016-2020) ulusal eylem planı. 12.01.2020 tarihinde https://www.ailevecalisma.gov.tr/uploads/ksgm/upload/pages/dagitimda -olan-yayin lar/kadina-yonelik-siddetle-mucadele-ulusal-eylem-plani2016-2020-icin-tiklayiniz. pdf adresinden erişildi.

Kalkınma Bakanlığı, (2013). Onuncu kalkınma planı 2014-2018. Ankara.

Keleş, R. (1996). Kentleşme politikası, Ankara: İmge Kitabevi.

Keleş, R. (2016). Kentleşme politikası (15. Baskı). Ankara: İmge Kitabevi.

Keskin ,E.B., Sağocak, M. ve Vural, A.(2015). Kentlilik bilinci çalışmaları için bir model önerisi: Bursa'da kentlilik bilinci araştırması. Paradoks Ekonomi Sosyoloji ve Politika Dergisi, 11(1), 21-43.

Kıray, M.(1982). Toplumsal değişme ve kentleşme. T. Erder (Der.) Kentsel bütünleşme içinde (s.57-66). Ankara: TGAV Yayınları.

Kocacık, F. ve Çağlayandereli, M. (2009). Ailede kadına yönelik şiddet: Denizli İli örneği. 03.02.2020 tarihinde http://wwww.insanbilimleri.com adresinden erişildi.

Köse, A. ve Beşer, A. (2007).Kadının değiştirilebilir yazgısı "şiddet". Atatürk Üniversitesi Hemşirelik Yüksekokulu Dergisi, 10(4), 114-121.

Okutan, Nur (2007). Kadına yönelik aile içi şiddet -Van'da, kadınların şiddet deneyimleri, şiddeti doğuran koşullar ve başetme biçimleri, şiddetin kadın sağlı̆̆ına etkileri. Yayımlanmamış Yüksek Lisans Tezi. 100. Yıl Üniversitesi,Sağlık Bilimleri Enstitüsü, Halk Sağlı̆̆ı Ana Bilim Dalı, Van.

KSGM (2016). Kadına yönelik şiddetle mücadele ulusal eylem planı 2016-2020. Aile Sosyal Politikalar Bakanlığı Kadının Statüsü Genel Müdürlügü̈, Ankara.

Özbudun, S. (2002). Küresel bir yoksulluk kültürü mü?, Y. Özdek (Der.), Yoksulluk, şiddet ve insan hakları içinde (s.53-69). Ankara:TODAİE Yayınları.

Öztürk, Ö. (2011). Türkiye'de kadına yönelik şiddet. Yayımlanmamış Yüksek Lisans Tezi. Marmara Üniversitesi, Sosyal Bilimler Enstitüsü, Hukuk Ana Bilim Dalı, İstanbul. 
Parlak, B. (2008). Kent kültürü ve kentlilik bilinci geliştirme projesi: Bursa Büyükşehir örneği, F. N. Genç, A. Yılmaz, H. Özgür (Ed.), Dönüşen kentler ve değişen yerel yönetimler içinde (s.61-85),Ankara: Gazi Kitabevi.

Parlak, B. (2011). Kamu yönetimi sözlüğ̈̈. Bursa: MKM Yayıncllı.

Sezal, İ. (1992). Kentleşme. Alternatif üniversite serisi. İstanbul:Ağaç Yayınları.

Sözcü Gazetesi (2020). Kadınlar 2019 yılında da katledildi. 03.02.2020 tarihinde https://www.sozcu.com.tr/hayatim/yasam-haberleril kadinlar2019-yilinda-da-katledildil adresinden erişildi.

Şimşek, B. (2019). Kadın cinayetleri neden önlenemiyor?. 03.01.2020 tarihinde https://www.bbc.com/turkce/haberler-turkiye-49492456, adresinden erişildi.

Tatar, Z. (2009). Yetişkinlerin kentlileşme ve eğitim ihtiyaçlarına ilişkin görüşleri (Eskişehir ili örneği). Yayımlanmamış Yüksek Lisans Tezi. Ankara Üniversitesi, Eğitim Bilimleri Enstitüsü, Ankara.

Tok, H.(2020). Meclis komisyonu kadın örgütleriyle ortak akıl yürütmeli. 03.02.2020 tarihinde https://www.sivilsayfalar.org/2020/01/10/ mecliskomisyonu-kadin-orgutleriyle-ortak-akilyurutmeli/ adresinden erişildi.

Uçar, A. (2016). İstatistiki verilerle ulusal basında kadına yönelik şiddet. İnönü Üniversitesi, Hukuk Fakültesi Dergisi, 7(2), 315-364.

Uğurluoğlu, B. (2018). Şiddet nedir? 03.02.2020 tarihinde, https://ailedenokula.com/siddetnedir?, adresinden erişildi.

UN WOMEN (2020). Facts and figures: ending violence against women, 13.02.2020 tarihinde http://www.unwomen.org/en/what-we-do/endingviolence-against-women/facts-and-figures adresinden erişildi.

World Health Organization. (2013). Responding to intimate partner violence and sexual violence against women - WHO clinical and policy guideline, World Health Organization.

World Bank (2000). World development report 2000/2001 attacking poverty. Washington D.C.: World Bank Publication.

\section{Kaynakça Bilgisi / Citation Information}

Alacadağlı, E. (2021). Kentlileşmeden kentleşme ve kadına şiddetin sosyal dinamikleri. OPUS-Uluslararası Toplum Araştırmaları Dergisi, 18(43), 7106-7138. DOI: 10.26466/opus. 913097. 